\title{
Between darkness and light: spring habitats provide new perspectives for modern researchers on groundwater biology
}

\author{
Raoul Manenti ${ }^{\text {Corresp., } 1,2}$, Beatrice Piazza ${ }^{1}$ \\ ${ }^{1}$ Department of Environmental Science and Policy, Università degli Studi di Milano, Milano, Lombardia, Italy \\ 2 Parco Regionale del Monte Barro, Laboratorio di Biologia Sotterranea “Enrico Pezzoli", Galbiate, Italy \\ Corresponding Author: Raoul Manenti \\ Email address: raoul.manenti@unimi.it
}

Springs are interfaces between groundwater and surface habitats and may play an important role in the study of subterranean animals. In this systematic evidence review and meta-analysis, we explore whether observations of stygobionts in springs are relevant and more common than observations of epigean animals in groundwater. We searched the Web of Science database for papers on groundwater fauna and spring fauna. For each paper we found, we recorded whether the paper reported the occurrence of typical stygobionts in springs, of surface animals in groundwater, or of the same taxa in both habitats. If so, we recorded how many such species were reported. We also recorded the scientific discipline of each study and the year of publication. Our search yielded 342 papers. A considerable number of these papers reported stygobionts in springs: $20 \%$ of papers dealing with groundwater fauna and $16 \%$ of papers dealing with spring fauna reported the occurrence of stygobionts in spring habitats. Both the number of papers that mentioned stygobionts in springs, and the number of stygobiont species that were documented in springs, were higher than equivalent measures for the occurrence of surface fauna underground. We also detected a positive relationship between year of publication and the number of reports of stygofauna in springs. To broaden the insights from biological research on underground environments, we suggest that springs should be considered not only as simple sampling points of stygobionts but also as core stygobiont habitats. 


\section{Between darkness and light: spring habitats provide}

3 new perspectives for modern researchers on

4 groundwater biology

Raoul Manenti ${ }^{1,2}$, Beatrice Piazza ${ }^{1}$

1 1Department of Environmental Science and Policy, Università degli Studi di Milano, via Celoria, 26, 20133 Milano Italy

${ }^{2}$ Laboratorio di Biologia Sotterranea "Enrico Pezzoli”, Parco Regionale del Monte Barro, 12 Galbiate, Italy.

Corresponding Author:

Raoul Manenti ${ }^{1}$

Email address: raoul.manenti@unimi.it

\section{Abstract}

Springs are interfaces between groundwater and surface habitats and may play an important role in the study of subterranean animals. In this systematic evidence review, we explore whether observations of stygobionts in springs are relevant and more common than observations of epigean animals in groundwater.

We searched the Web of Science database for papers on groundwater fauna and spring fauna. For each paper we found, we recorded whether the paper reported the occurrence of typical stygobionts in springs, of surface animals in groundwater, or of the same taxa in both habitats. If so, we recorded how many such species were reported. We also recorded the scientific discipline of each study and the year of publication.

Our search yielded 342 papers. A considerable number of these papers reported stygobionts in springs: $20 \%$ of papers dealing with groundwater fauna and $16 \%$ of papers dealing with spring fauna reported the occurrence of stygobionts in spring habitats. Both the number of papers that mentioned stygobionts in springs, and the number of stygobiont species that were documented in springs, were higher than equivalent measures for the occurrence of surface fauna underground. stygofauna in springs. 
37 To broaden the insights from biological research on underground environments, we suggest that 38 springs should be considered not only as simple sampling points of stygobionts but also as core 39 stygobiont habitats.

40

41

\section{Introduction}

43 The zoologist Lazăr Botoșăneanu (1998) defined springs as the "doors on River Styx," the river 44 of the Greek mythological underworld. Other biologists who study subterranean environments and 45 groundwaters similarly consider springs to be openings that allow them to see the inhabitants of 46 an otherwise inaccessible environment (Culver et al. 2012; Fiasca et al. 2014; Galassi et al. 2014;

47 Pipan \& Culver 2012; Pipan et al. 2012). This view of spring habitats as windows into a different 48 environment is particularly true in non-karst areas, where the lack of caves prevents human exploration of the subterranean realm and springs are often the only way to access groundwater organisms (Manenti \& Pezzoli 2019). Springs are interfaces between groundwater and surface

\section{1 freshwaters}

with a great variety of connectivity, permeability and biodiversity (Gibert et al. 1997; Kresic 2010; Springer \& Stevens 2009). The interplay of both subterranean and epigean habitat features that characterises springs (Alfaro \& Wallace 1994; Cantonati et al. 2006), makes challenging to define the spatial boundaries of these ecotones (Gibert et al. 1997).

In some cases the transition between surface and subterranean habitats, may also be abrupt; indeed, the magnitude of this transition strongly depends on the morphology of the spring and can be mutable with daylight. Some springs represent an abrupt shift from the subterranean environment to the surface, whereas others, like the natural emitting caves (such as caves from which subterranean streams flow outside) of artificial draining galleries (such as galleries built to collect groundwater), represent extended ecotonal environments (Balland 1992; White 2019). The border between the subterranean and surface environment can be particularly distinct during daytime, 
63 when it is strictly demarcated by the sun. Aside from sunlight, the differences that distinguish

64 subterranean and surface environments in a spring, even across the few meters or centimetres that

65 may characterize a spring with a sudden interface (Fig. 1), include the availability of trophic

66 resources, the density of potential predators, and microclimate conditions (Barzaghi et al. 2017;

67 MacAvoy et al. 2016; Manenti et al. 2013; Von Fumetti \& Nagel 2011).

68 Because springs are border habitats, it can be difficult for biological studies to consider springs in 69 their entirety; this difficulty has limited the potential for insights from springs to drive stronger 70 advances in different fields of research. For example, studies that focus on springs often only 71 consider a surface perspective and neglect the role played by groundwater (Manenti \& Pezzoli 72 2019), whereas in karst areas, scientists studying the subterranean environment see springs as 73 "access points" that can be used to sample the groundwater fauna living in different subterranean, 74 underwater environments, such as the phreatic zone of karst aquifers (Malard et al. 2002). This 75 latter view reflects the scarce consideration that is often given to springs and may limit a more 76 general understanding of the ecological role of border habitats. As some studies have already 77 suggested, transition zones are important for regulating ecosystem processes and the flow of 78 organic matterand organisms between surface (epigean) and underground (hypogean) habitats 79 (Moseley 2009; Plenet \& Gibert 1995; Prous et al. 2004). With this opinion paper based on a 80 systematic review of the recent scientific literature, we aim to stimulate a change in the conception 81 of and in the approach to springs by studies dealing with stygobionts and groundwater fauna. 82 Particularly we want to underline that springs have the potential to reveal general patterns related 83 to the zoology of stygobionts.

84 Stygobionts are obligate groundwater-dwellers; the etymology of the word "stygobiont" reflects 85 the fact that these species, and stygofauna more broadly, are "of the River Styx." These organisms 
86 have evolved adaptations specific to the underground freshwater habitats in which they spend their

87 entire life cycle (Trajano \& De Carvalho 2017). Stygobionts often exhibit morphological features

88 associated with their underground habitat. These characteristics, such as blindness and

89 depigmentation, are commonly referred to as troglomorphisms (Pipan \& Culver 2012; Romero

90 2009), and they limit stygobionts' ability to exploit surface environments. However, at night, the

91 constraints are generally less clear and surface borders (i.e., springs) may become more permeable

92 by stygofauna; for example, some samplings of springs' fauna have reported during night the

93 occurrence of organisms considered to be strict stygobionts (Bressi et al. 1999; Fišer 2019;

94 Manenti \& Barzaghi 2020; Manenti \& Barzaghi In press), as it has been observed also for the

95 twilight zones of terrestrial caves (Mammola \& Isaia 2018). One such case is that of Stygobromus

96 amphipods, which are believed to regularly leave hypotelminorheic habitats to feed (Culver et al.

97 2006; Culver \& Pipan 2014). Nevertheless, these findings are often viewed as exceptions or

98 accidental events, and the use of springs is rarely mentioned as a trait of stygobiont biology.

99 Observations of surface animals in caves have been similarly overlooked in the past (Sket 2008)

100 and improperly seen as accidental; such "accidental" observations have recently been described

101 for both groundwater and terrestrial subterranean habitats (Ficetola et al. 2018; Lunghi et al. 2014a;

102 Manenti 2014).

103 Stygobionts are the main focus of subterranean biology and are usually studied using two distinct

104 approaches. The first approach includes intense taxonomic investigations focused on the discovery

105 and description of new taxa. The second approach views caves as powerful natural laboratories for

106 evolutionary, ecological and behavioural studies on their inhabitants (Culver \& Pipan 2014; Culver

107 \& Pipan 2019). The idea of caves as natural laboratories, first postulated by the speleologist

108 Édouard-Alfred Martel (1894), has been espoused for more than one hundred years of subterranean 
109 studies (Poulson \& White 1969) and recently updated and broadened in the current context of

110 biological research (Mammola 2019; Mammola et al. 2020). However, of the relatively large

111 number of caves that were effectively used as laboratories during last century (Vandel 1964), few

112 remain active. In addition, the outcomes of studies on stygofauna in these caves is rarely compared

113 to insights obtained from studies of surface freshwater organisms. This is partially due to the

114 characteristic features of stygobionts: they are often difficult to sample in deep subterranean

115 environments and springs can be seen as useful sampling points for them, using a combination of

116 different methods depending on the spring morphology and hydrology (Malard et al. 2002).

117 Particularly in springs are recommended the sampling of drifting stygobionts during spates,

118 samplings of the spring benthic layer, and bed sediments and also the use of artificial substrates

119 and baited traps (Malard et al. 2002).

120 Moreover, due to their long life cycles and low fertility, stygobionts are difficult to raise in an

121 experimental settings. Would including springs and other surface/underground border habitats in

122 studies on subterranean biology increase the understanding of how the constraints of the hypogean

123 environment affect the phenotypic responses and genetic makeup of stygobionts? The rationale of

124 this paper takes origin from this question and is to suggest that a substantial inclusion of springs

125 (and other border habitats between underground and surface) in studies on subterranean biology,

126 can increase the understanding of principles governing exploitation and adaptation to hypogean

127 environments.

128 In this paper, we investigate the perspectives of modern researchers on considering springs not 129 only as simple sampling points, but also as core stygobiont habitats that can broaden the insights 130 obtained from biological studies of underground environments. We specifically performed a 131 systematic review of the recent scientific literature to understand i) the relevance of previous 
132 observations of typical stygobionts in springs; ii) if these observations vary according with study

133 discipline and the year of publication; and iii) if these observations are more common than

134 observations of epigean animals (i.e. aquatic surface species) in caves. By demonstrating that

135 typical stygofauna are observed in springs more commonly than usually thought, we propose that,

136 at least in some cases, the exploitation of border habitats be considered a non-negligible aspect of

137 stygofauna ecology.

\section{Survey methodology}

139 To avoid bias, many scientific fields have largely started to favour the use of systematic evidence

140 reviews (Acreman et al. 2020). We therefore performed a systematic review to find focused data

141 that addressed our three aims (Table 1). For this review, we followed the Preferred Reporting Items

142 for Systematic Reviews (PRISMA) guidelines (Page \& Moher 2017), and we searched the Web of

143 Science database for peer-reviewed papers on both stygofauna and fauna living in spring habitats

144 (Fig. 2). The Web of Science database contains metadata for peer-reviewed scientific articles

145 published since 1965 . We used two search strings designed to find all articles in the database that

146 might contain observations of fauna in both caves and springs. Our search was conducted in May

1472020 from Milano, Italy, using the keywords "groundwater fauna" (GF) and "spring fauna

148 freshwater" (SFF) and searching them by topics. For the search we used a ASUS K501 PC and the

149 Google Chrome browser, after having emptied its cache box.

150 One of us (BP) initially screened the articles that met our search criteria by discarding articles that

151 were not clearly related to our study aims. She rejected articles about botany, palaeontology,

152 geology, and all their associated subdisciplines (paleoecology, stratigraphy, geomorphology, etc.),

153 as well as articles about subterranean environments or groundwater that did not mention animals.

154 The articles found using the key words "spring fauna freshwater" were more difficult to screen;

155 for the most part, the authors of these articles did not specify if their study species were part of 
156 stygofauna or not. She therefore discarded these articles only if they were not related to our study

157 aims (e.g., papers about estuaries, palaeontology, or related topics) or if the authors provided clear

158 evidence that the study species were not cave-dwellers.

159 She additionally discarded several articles that dealt strictly with agricultural sciences, 160 biogeochemical cycles, the impacts of various pollutants (crude oils, perchlorate, etc.) on 161 groundwater, or other environments strongly connected to groundwater (i.e., all surface water 162 environments), but did not mention the finding of stygofauna or epigean fauna. She discarded also 163 articles that addressed single species or taxa that are not stygofauna or typical spring fauna and 164 have no hypogean representatives (e.g., Rechulicz 2011 treated Pseudorasbora parva and Vilenica 165 et al. 2016 treated mayflies). Articles concerning terrestrial environments, estuaries, swamps, 166 mangroves, streams, rivers, lakes, and all saltwater environments, were similarly discarded (see 167 Table 1 for more detailed information on the article selection procedure). After this first screening, 168 she performed a second selection procedure in which she removed any articles that were 169 unavailable or were written in a language other than English.

170 From the papers she collected the information listed in Table 1, including the typology of the study,

171 distinguishing between ecology, taxonomy behaviour, conservation and fauna assessment and 172 considering that the same paper could belong to multiple categories. Moreover, she assessed the 173 country and the continent of origin of the data provided by the papers.

\section{Statistical analyses}

175 To assess the relationships between features of the selected documents and the occurrence of 176 stygofauna in springs, we built a series of generalized linear models (GLMs) with binomial error 177 distributions. 
178 First, we assessed if the fact that a paper reported the occurrence of stygobionts in springs, the

179 occurrence of surface fauna in groundwaters, or the contemporary occurrence of a stygobiont in 180 both groundwaters and springs, was related to the paper's field of study. Reported occurrences 181 were used as the dependent variable, and the study disciplines (ecology, taxonomy, faunal 182 assessment, and conservation) were used as fixed factors (Equation 1). We similarly built GLMs with the same dependent variable but with publication year and the search term as independent variables (Equation 2).

185

186

187

188

189

190

191

192

193

194

195

196

197

Stygofauna found in springs OR Surface fauna underground OR

Occurrence of the same taxa in Same taxa both in springs and groundwaters $\sim$ Ecology + Taxonomy + Fauna.assessment + Conservation + Behaviour, family $=$ binomial .

\section{Stygofauna found in springs OR Surface fauna underground OR}

Occurrence of the same taxa in Same taxa both in springs and groundwaters Year of publication + as.factor $($ key research term $)$, family $=$ binomial.

Second, using only the papers selected with the GF search term we built GLMs to test two distinct hypotheses: (1) that the number of mentions of stygobiont species in springs is higher than the number of mentions of surface species in groundwater; and (2) that missing information is different among the two situations. Both hypotheses were tested only for papers selected with the keyword "groundwater fauna" to avoid biases associated with the fact that studies found using the keyword "spring fauna freshwater" may not have sampled underground habitats. For the first test (Equation 3), we used the number of species mentioned by each paper as a dependent variable, including 
201 both stygofauna found in springs and surface fauna found underground. The type of observation 202 (stygofauna in springs vs. surface fauna in groundwater) was used as a fixed factor.

203

Number of species mentioned $\sim$ Typology of observation, family = nbinom 2.

205

206 For the second test (Equation 4), we defined the dependent variable as whether it was possible to 207 assess the number of species mentioned in a study, including both types of observations 208 (stygofauna in springs and surface fauna in groundwater). The type of observation was used as a 209 fixed factor, as before.

210

211

212

213

214 215 216 217 sampling of the springs.

218 For all models we checked models assumptions by verifying the absence of multicollinearity issues 219 220 221 222 223

$$
\text { NAns occurrence } \sim \text { Typology of observation, family }=\text { nbinom } 2 .
$$

Third, we also built a series of GLMs to test if the fact that a paper reported the occurrence of stygobionts in springs, the occurrence of surface fauna in groundwaters, or the contemporary occurrence of a stygobiont in both groundwaters and springs, was related to the continent of though VIF calculation and plotting residuals versus fitted values, versus each covariate; To avoid overdispersion bias in the models used for the second step of analysis, we built both models using a type 2 negative binomial error distribution in the package glmmTMB (Brooks et al. 2017).

We used a likelihood ratio test to assess the significance of all the fixed factors included in each GLM (Bolker et al. 2008). All analyses were performed in the R 3.6.3 environment. 


\section{Results}

226 We retrieved 824 potentially relevant papers after removing duplicate articles. After removing 227 articles based on the first selection criteria described above, there were 415 potentially relevant 228 documents. After the second selection procedure, we obtained 342 papers: 275 derived from the 229 search term "groundwater fauna" (GF) and 67 from the search term "spring fauna freshwater" 230 (SFF). Many papers found using the "groundwater fauna" search did not specify the sampling site 231 for the taxa considered, and many papers found using the "spring fauna freshwater" search did not 232 clearly identify if they sampled stygofauna or not. Overall, 57 papers (representing 19\% of the 233 papers with information on sampling habitat) reported the occurrence of stygofauna in springs, 37

$234(11.7 \%)$ reported the occurrence of typical surface fauna underground, and $33(11 \%)$ reported the 235 same taxa in both springs and groundwater (Table 2). With respect to our search terms, $20 \%$ of 236 papers dealing with GF and 16\% of papers dealing with SFF described the occurrence of 237 stygobionts in spring habitats.

238 There were 45,375 mentions of species across all papers we retrieved. Of these, 138 were 239 stygobionts observed/sampled in springs and 46 were surface species observed in subterranean 240 habitats.

241 The study disciplines covered by the papers were mainly ecology (196 papers) and faunistic 242 assessments (177 papers). Four papers were behavioural studies, and 24 papers addressed 243 conservation issues. There were 194 papers that encompassed multiple ad hoc definitions that we 244 established in the methods.

245 Our first analysis revealed that faunal assessments are significantly more likely to report the 246 occurrence of surface fauna in groundwater, whereas taxonomic studies are more likely to report 247 the occurrence of the same taxon in both environments (Table 3). We did not detect any 
248 relationship between the discipline of a paper (ecology, taxonomy, etc.) and the reported

249 occurrence of stygofauna in springs. However, we did detect a positive relationship between the

250 year of publication and the reports of stygofauna in springs $\left(\chi^{2}=4.53, \mathrm{P}=0.03\right)$. Papers selected

251 using the SFF search term were significantly less likely to report the occurrence of surface taxa in

252 groundwaters $\left(\chi^{2}=4.09, \mathrm{P}=0.04\right)$.

253 Most data of the papers came from Europe (59.76\%) and Oceania (27.9 \%); we detected no

254 significant relationships between the continent of sampling and the occurrence of stygobionts in 255 springs, the occurrence of surface fauna in groundwaters, and the contemporary occurrence of a 256 stygobiont in both groundwaters and springs.

257 GLMs performed on papers selected using the GF search term revealed that the number of 258 mentions of stygobiont species in springs is higher than the number of mentions of surface fauna 259 underground $\left(\chi^{2}=4.19, \mathrm{P}=0.04\right)$. However, there is also less information available on whether 260 stygofauna have been observed in springs compared to whether surface species have been recorded 261 in groundwaters $\left(\chi^{2}=14.08, \mathrm{P}<0.001\right)$.

\section{Discussion and perspectives}

263 Our systematic review revealed that there are more papers about stygofauna available on Web of 264 Science than there are papers addressing fauna and springs. Because the word "spring" is a 265 homograph with multiple meanings, our initial search retrieved many papers that were ultimately 266 discarded because they did not discuss fauna and spring habitats. Preliminary literature searches 267 performed using synonyms of "spring" and/or terms that define specific spring habitats, such as 268 "sources" or "seepage," resulted in fewer papers. Most of these papers were already included in 269 our analysis; however, the few that were not could be used in future study with a larger set of 270 papers. Someone could disagree as it is likely that our research missed some papers (as an example 271 we are sure that we missed at least 15 papers on aquatic cave-dwelling salamanders and 10 papers 
272 on the taxonomy of strictly subterranean planarians) and that further keywords should have been

273 added, for example: stygob*, ecoton*, hypogean, subterranean etc, but they would have increased

274 the number of papers dealing with stygofauna without significant increase in the number of papers

275 related to spring fauna. The large difference in the number of papers obtained with the two search

276 terms, GF and SFF, underscores the fact that the fauna of spring habitats have received much less

277 attention not only than the inhabitants of lakes and streams/rivers, as already pointed out by

278 previous studies (Cantonati et al. 2011), but also than stygofauna.

279 We limited our review to articles archived in Web of Science; this approach was more conservative

280 because it included only relatively recent papers published in indexed, high-impact journals that

281 perform selective peer review. An analogous review could be performed using the Google Scholar

282 database or a more exhaustive search of grey literature in online and physical repositories. It is

283 possible that the older, descriptive papers archived in these databases may have reported

284 stygofauna in springs, but it is also possible that some form of bias could arise from using older

285 literature that has not been rigorously peer reviewed. The effects of database selection should

286 therefore be investigated in the future.

287 Using both GF and SFF as search terms, we found papers that mentioned the occurrence of 288 stygofauna in springs, of typical surface fauna in groundwaters, and of the same taxa in both 289 environments. The number of papers that reported stygofauna in springs, as well as the number of 290 stygobiont species that were documented in springs, represented only a fraction of the total papers 291 and documented species but were nevertheless non-negligible. This pattern was not linked to any 292 specific field of study; though taxonomic studies were non-significantly more likely to report 293 stygofauna in springs. 
294 Springs have been recognized as relevant habitats for studying stygobionts since the beginning of 295 the $19^{\text {th }}$ century. Most subterranean biologists devoted at least some of their studies to spring 296 habitats (Culver et al. 2012; Culver et al. 2014; Vandel 1920), and Albert Vandel, the founder of 297 the "Laboratoire Souterrain de Moulis" (France), one of the most popular subterranean laboratories 298 in the world (Botosaneanu 1980), stated in 1920 that a systematic study of spring habitats could 299 furnish important insights for solving some of the evolutionary questions posed by cave-dwelling 300 animals (Vandel 1920). However, this concept appears only in Vandel's conclusions and is not 301 further developed; the idea that springs are just sampling points in non-karst areas largely prevails 302 throughout the rest of the paper (Vandel 1920).

303 Stygobionts are known to colonize the mixed assemblages of organisms residing in springs via 304 emigration and drift from groundwaters (Malard et al. 2009; Malard et al. 2002; Manenti \& 305 Barzaghi In press). Typical stygobionts may be more or less permanently detected outside the 306 spring outlet, where they can exploit different microhabitats (Malard et al. 2002; Mathieu et al. 307 1994). This is especially true when there is a stable supply of immigrants from karst groundwater (Mathieu et al. 1999). Our results revealed that there is a positive significant correlation with the reporting of typical stygobionts in springs and the year of publication; this means that, with respect to older studies, researchers are paying more attention when reporting data on sample collection 311 habitats, regardless of their study discipline (ecology, taxonomy, conservation, or faunal 312 assessment). However, in the papers that we collected, the occurrence of stygobionts in springs 313 was often reported as either an effect of the sampling method or an occasional finding. None of 314 the papers assessed patterns in the use of springs by stygobionts. This is true also for some papers 315 that we missed with our search but that are well known in spring literature. As an example (Rouch 316 1986) defined "the hemorrhage" the flow of stygofauna pushed out from aquifers during high 
317 discharge periods through springs, erroneously considering this only as a passive mechanism. Also

318 the case of the olm (Proteus anguinus) is challenging with both mentions of cases of passive drift

319 of individuals from groundwaters (Aljančič 2019) and hypotheses of active exploitations of spring

320 habitats (Bressi et al. 1999). In more recent times, some papers were devoted to spring discharge

321 and the passive presence of stygobionts being flushed from "conductive" or "capacitive" aquifers

322 (Di Lorenzo et al. 2005); other large-scale ecological surveys of springs demonstrated that in 323 mountain areas, where species richness of stygobionts is usually poor due to the effect of

324 Quaternary Galciations, their occurrence seems low or occasional in springs (Stoch et al. 2011),

325 suggesting that the geographical location of springs matters and could be more in depth considered

326 in future systematic reviews dealing with springs. Springs are also being studied with recent and

327 'modern' approaches like DNA metabarcoding techniques and eDNA that can allow to detect the 328 presence of stygobionts in springs (West et al. 2020; White et al. 2020; Yonezawa et al. 2020) and

329 be used in the future to assess the patterns that determine this occurrence.

330 The occurrence of a stygobiont species, or a species that is strictly linked to a hypogean

331 groundwater habitat for its life cycle, in an epigean spring habitat, underlines a contradiction that

332 might reflect the human conceptual limit of understanding borders. The human perception of limits

333 and boundaries may be biased, as humans may recognize or emphasize abrupt distinctions when

334 they do not exist (Pirni 2016; Sturz \& Bodily 2016). Our results demonstrate that, at least for some 335 stygobionts, border habitats and adjacent areas are an important part of the range and biology of 336 stygofauna, and a proper consideration of these habitats in subterranean biology studies could 337 provide larger perspectives. For example, stygobiont populations or individuals that exploit springs

338 more or less permanently are likely exposed to different constraints and advantages than 339 populations or individuals that exploit deeper aquifers. Selective pressures may therefore act 
340 differently, at least for the individuals living in springs or at the interface between subterranean

341 and epigean habitats.

342 For example, different species and/or populations of the genus Niphargus, which shows typical

343 features of stygobionts including depigmentation and the absence of eyes, have the unique ability

344 to detect light (Fišer et al. 2016). This ability has been associated with the need to distinguish the

345 border between surface and subterranean environments and avoid risky surface habitats (Fišer et

346 al. 2016) where UV rays may be dangerous for a depigmented animal. However, surface habitats

347 may also be advantageous by furnishing higher trophic resources and, at night, they are not

348 exposed to UV light. Several studies have reported Niphargus amphipods in border habitats (Fiser

349 et al. 2007; Manenti \& Pezzoli 2019; Marković et al. 2018). Is light perception the same between

350 individuals from borders and individuals from deeper aquifers? Are there evolutionary adaptations

351 for exploiting not only deep subterranean habitats but also border habitats at the interface with the

352 surface? These questions are applicable to all stygobionts that are recurrently found in springs.

353 Considering border habitats in addition to deeper subterranean environments therefore has the

354 potential to double the insights obtained from studies of stygobionts. These insights could be used

355 not only to disentangle evolution from the adaptations to the selective pressures of groundwater

356 habitats but also to characterize the physiological responses stimulated by the interaction with

357 different environmental conditions.

358 Our results further demonstrate that stygofauna are reported in springs more frequently than

359 surface fauna are reported in groundwater, in terms of both number of papers and overall numbers

360 of species. In recent years, a growing body of literature has shown that even the occurrence of

361 surface species in caves is often not accidental (Lunghi et al. 2014b; Lunghi et al. 2017), a finding

362 that has important implications for the communities of shallow subterranean habitats (Kozel et al. 
363 2019; Lunghi 2018; Lunghi et al. 2020; Salvidio et al. 2020; Silva et al. 2020). If stygofauna occur

364 in springs and adjacent microhabitats more commonly than surface fauna occur underground, it is

365 likely that, at least for some stygobionts, the use of the surface environment is not accidental.

366 Further systematic reviews and analyses of the literature on spring fauna could be performed to

367 investigate the countries where the largest number of studies on springs were carried out, the most

368 studied taxa and the most studied functional traits.

369 A parallel can be made between springs and marine caves which can further support the idea that 370 springs are just an ecotone that should also be studied from an ecological viewpoint (Romero, in

371 litteris). For example, there are sea fish species that enter and exit marine caves playing a 372 significant role in those environments' ecology. That is the case with the cardinal fish Apogon 373 imberbis. This is a small-sized fish distributed along the eastern Atlantic coast from Morocco to 374 the Gulf of Guinea, including the Azores. It can be found as solitary or forming schools and is 375 common in small crevices to marine caves, where they can be found in large densities. They show 376 no troglomorphisms, yet they play a significant role in transferring organic material to these marine 377 caves as mysid crustaceans do (Romero, in litteris). Like bats and Dolichopoda cave crikets 378 (Mammola \& Isaia 2018), they tend to stay in the shelters during the day and leave the caves at 379 night, presumably for feeding (Bussotti et al. 2003).

380 The occurrence of stygobionts in springs could affect both the dynamics of boundary habitats and, 381 at the level of the whole stygobiont population, the intrinsic traits of the species. There are several 382 different perspectives for how a stronger conceptual inclusion of springs in subterranean research 383 may provide additional insights on subterranean biology. First, springs may favour intraspecific 384 variation that could be assessed by comparative experimental studies, which would benefit studies 385 of intraspecific dynamics between boundaries and deep areas. Second, springs can inform studies 
386 of the processes that promote adaptation to and colonization of border habitats, as research on

387 springs could be used to distinguish possible phenotypic plasticity from local adaptations. Third, 388 given the view of springs as useful laboratories, devoting space and infrastructure at the entrance 389 to subterranean environments could provide important experimental opportunities.

\section{Conclusions}

391 Even if the transitional and ecotonal role of springs is known and studied since several decades,

392 and the term Groundwater Dependent Ecosystems applied to springs (Fattorini et al. 2020; Rohde 393 et al. 2017) allows to study the connected network of surface and subterranean ecosystems 394 following the 'holistic' approach suggested by (Linke et al. 2019), these concepts are rarely 395 translated in ecological and evolutionary studies dealing with groundwater animals. The results of 396 our systematic review broadly suggest that springs and other boundaries with surface environments 397 should be considered and investigated as part of subterranean habitats and of the biology of at least 398 some stygobionts. Studies of groundwater environments and stygobiont biology that do not 399 consider springs may furnish only a limited perspective on subterranean environments, because 400 they could exclude a priori a potential source of selective pressures for groundwater-dwelling 401 animals. The study of groundwater-adapted organisms in subterranean aquifers has the potential 402 to reveal new insights in several scientific fields (Pipan \& Culver 2013; Reboleira et al. 2011), but 403 the study of the boundaries of groundwater environments, such as springs, is not only equally 404 important, but even necessary to understand the zoology ecology and evolution of groundwater 405 fauna.

\section{Acknowledgements}


410 We are grateful to Prof. David Culver and Prof. Aldemaro Romero Jr. for comments and 411 suggestions on an early draft of this manuscript. The comments of Stefano Mammola and of an 412 anonymous reviewer improved the quality of the manuscript.

\section{References}

414 Acreman M, Hughes KA, Arthington AH, Tickner D, and Duenas MA. 2020. Protected areas 415 and freshwater biodiversity: a novel systematic review distils eight lessons for effective $416 \quad$ conservation. Conservation Letters 13. 10.1111/conl.12684

417 Alfaro C, and Wallace M. 1994. Origin and classification of springs and historical review with $418 \quad$ current applications. Environmental Geology 24:112-124.

419 Aljančič G. 2019. History of research on Proteus anguinus Laurenti 1768 in Slovenia. . Folia 420 Biologica et Geologica 60:39-69.

421 Balland D. 1992. Les eaux cachées. Études géographiques sur les galleries drainantes 422 souterraines. Paris: Departement de Géographie, Univers Sorbonne.

423 Barzaghi B, Ficetola GF, Pennati R, and Manenti R. 2017. Biphasic predators provide biomass subsidies in small freshwater habitats: A case study of spring and cave pools. Freshwater Biology 62:1637-1644. DOI: 10.1111/fwb.12975

Bolker BM, Brooks ME, Clark CJ, Geange SW, Poulsen JR, Stevens MHH, and White JS. 2008. Generalized linear mixed models: a practical guide for ecology and evolution. Trends in Ecology and Evolution 24:127 - 135.

Botosaneanu L. 1980. Karstic ecosystem - 10 years of hydrobiological studies at CNR 
431 Botosaneanu L. 1998. Sources: aux portes du Styx (Springs: gates to and from the Styx). In:

432

433

434

435

436

437

438

439

440

441

442

443

444

445

446

447

448

449

450

451

452

453

Botosaneanu L, ed. Studies in Crenobiology- The biology of springs and springbooks

Leiden: Bachuys Publishers, 229-250.

Bressi N, Aljancic M, and Lapini L. 1999. Notes on presence and feeding of Proteus anguinus Laurenti, 1768 outside caves. Rivista di Idrobiologia 38:431 - 435.

Brooks ME, Kristensen K, van Benthem KJ, Magnusson A, Berg CW, Nielsen A, Skaug HJ, Machler M, and Bolker BM. 2017. glmmTMB Balances Speed and Flexibility Among Packages for Zero-inflated Generalized Linear Mixed Modeling. R Journal 9:378-400.

Bussotti S, Guidetti P, and Belmonte G. 2003. Distribution patterns of the cardinal fish, Apogon imberbis, in shallow marine caves in southern Apulia (SE Italy). Italian Journal of Zoology 70:153-157.

Cantonati M, Gerecke R, and Bertuzzi E. 2006. Springs of the Alps - sensitive ecosystems to environmental change: from biodiversity assessments to long-term studies. Hydrobiologia 562:59-96.

Cantonati M, Gerecke R, Juttner I, and Cox EJ. 2011. Springs: neglected key habitats for biodiversity conservation Introduction to the Special Issue. Journal of Limnology 70:1-1.

Culver D, Pipan T, and Gottstein S. 2006. Hypotelminorheic-a unique freshwater habitat. Subterranean Biology 4:1.

Culver DC, Holsinger JR, and Feller DJ. 2012. The Fauna of Seepage Springs and Other Shallow Subterranean Habitats in the Mid-Atlantic Piedmont and Coastal Plain. Northeastern Naturalist 19:1-42. 10.1656/045.019.m901

Culver DC, and Pipan T. 2014. Shallow Subterranean Habitats: Ecology, Evolution, and Conservation. New York, NY, USA: Oxford University Press. 
454 Culver DC, and Pipan T. 2019. The biology of caves and other subterranean habitats. New $455 \quad$ York: Oxford University Press.

456 Culver DC, Pipan T, Culver DC, and Pipan T. 2014. Seepage springs and the hypotelminorheic $457 \quad$ habitat.

458 Di Lorenzo T, Cipriani D, Bono P, Rossini L, De Laurentiis P, Fiasca B, Pantani C, and Galassi 459 DMP. 2005. Dynamics of groundwater copepod assemblages from the Mazzoccolo $460 \quad$ karstic spring (central Italy). Meiofauna Marina 14:97-103.

461 Fattorini S, Fiasca B, Di Lorenzo T, Di Cicco M, and Galassi DMP. 2020. A new protocol for 462 assessing the conservation priority of groundwater-dependent ecosystems. Aquatic Conservation-Marine and Freshwater Ecosystems 30:1483-1504. 10.1002/aqc.3411

464 Fiasca B, Stoch F, Olivier M, Maazouzi C, Petitta M, Di Cioccio A, and Galassi DMP. 2014. The dark side of springs: what drives small-scale spatial patterns of subsurface meiofaunal assemblages? Journal of Limnology 73:71 - 80.

467 Ficetola GF, Lunghi E, Canedoli C, Padoa-Schioppa E, Pennati R, and Manenti R. 2018. Differences between microhabitat and broad-scale patterns of niche evolution in terrestrial salamanders. Scientific Reports 8:10575.

Fišer C. 2019. Niphargus-A model system for evolution and ecology. In: White WB, Culver DC, and Pipan T, eds. Encyclopedia of Caves. Cambridge, MA, USA: Academic Press, 472 746-755.

473 Fiser C, Zaksek V, Zagmajster M, and Sket B. 2007. Taxonomy and biogeography of Niphargus steueri (Crustacea : Amphipoda). Limnology 8:297-309. 10.1007/s10201-007-0221-5 
475 Fišer Z, Novak L, Lustrik R, and Fiser C. 2016. Light triggers habitat choice of eyeless

476 subterranean but not of eyed surface amphipods. Science of Nature 103:7.

477 $10.1007 / \mathrm{s} 00114-015-1329-9$

478 Galassi DMP, Lombardo P, Fiasca B, Di Cioccio A, Di Lorenzo T, Petitta M, and Di Carlo P. 479 2014. Earthquakes trigger the loss of groundwater biodiversity. Scientific Reports 4.

480 Gibert J, Mathieu J, and Fournier F. 1997. Groundwater/surface ecotones: biological and 481 hydrological interactions and masnagement options. Cambridge, UK: University Press.

482 Kozel P, Pipan T, Mammola S, Culver DC, and Novak T. 2019. Distributional dynamics of a 483 specialized subterranean community oppose the classical understanding of the preferred subterranean habitats. Invertebrate Biology 138. 10.1111/ivb.12254

485

486

487

488

489

490

491

492

493

494

495

Kresic N. 2010. Types and classifications of springs. In: Kresic N, and Stevanovic Z, eds. Groundwater hydrology of springs Engineering, theory, management, and sustainability. Amsterdam, The Netherlands.: Elsevier Press, 31-86.

Linke S, Turak E, Asmyhr MG, and Hose G. 2019. 3D conservation planning: Including aquifer protection in freshwater plans refines priorities without much additional effort. Aquatic conservation.

Lunghi E. 2018. Ecology and life history of Meta bourneti (Araneae: Tetragnathidae) from Monte Albo (Sardinia, Italy). Peerj 6. 10.7717/peerj.6049

Lunghi E, Ficetola GF, Zhao YH, and Manenti R. 2020. Are the Neglected Tipuloidea Crane Flies (Diptera) an Important Component for Subterranean Environments? Diversity-Basel 12. $10.3390 / \mathrm{d} 12090333$ 
496 Lunghi E, Manenti R, and Ficetola GF. 2014a. Do cave features affect underground habitat 497 exploitation by non-troglobite species? Acta Oecologica 55:29 - 35.

$498 \quad$ 10.1016/j.actao.2013.11.003.

499 Lunghi E, Manenti R, and Ficetola GF. 2014b. Do cave features affect underground habitat 500 exploitation by non-troglobite species? Acta Oecologica-International Journal of

501 Ecology 55:29-35. 10.1016/j.actao.2013.11.003

502

Lunghi E, Manenti R, and Ficetola GF. 2017. Cave features, seasonality and subterranean

503 distribution of non-obligate cave dwellers. Peerj 5:e3169. DOI: 10.7717/peerj.3169

504

505

506

507

508

509

510

511

512

513

514

515

516

517

MacAvoy SE, Braciszewski A, Tengi E, and Fong DW. 2016. Trophic plasticity among spring vs. cave populations of Gammarus minus: examining functional niches using stable isotopes and C/N ratios. Ecological Research 31:589-595. 10.1007/s11284-016-1359-6

Malard F, Boutin C, Camacho AI, Ferreira D, Michel G, Sket B, and Stoch F. 2009. Diversity patterns of stygobiotic crustaceans across multiple spatial scales in Europe. Freshwater Biology 54:756-776.

Malard F, Dole-Olivier MJ, Mathieu J, and Stoch F. 2002. Sampling Manual for the Assessment of Regional Groundwater Biodiversity. Lyon: PASCALIS Project.

Mammola S. 2019. Finding answers in the dark: caves as models in ecology fifty years after Poulson and White. Ecography 42:1331-1351. 10.1111/ecog.03905

Mammola S, Amorim IR, Bichuette ME, Borges PAV, Cheeptham N, Cooper SJB, Culver DC, Deharveng L, Eme D, Ferreira RL, Fiser C, Fiser Z, Fong DW, Griebler C, Jeffery WR, Jugovic J, Kowalko JE, Lilley TM, Malard F, Manenti R, Martinez A, Meierhofer MB, Niemiller ML, Northup DE, Pellegrini TG, Pipan T, Protas M, Reboleira A, Venarsky 
518

519

520

521

522

523

524

525

526

527

528

529

530

531

532

533

534

535

536

537

538

539

540

MP, Wynne JJ, Zagmajster M, and Cardoso P. 2020. Fundamental research questions in subterranean biology. Biological Reviews 95:1855-1872. 10.1111/brv.12642

Mammola S, and Isaia M. 2018. Day-night and seasonal variations of a subterranean invertebrate community in the twilight zone. Subterranean Biology 27:31-51.

\subsection{7/subtbiol.27.28909}

Manenti R. 2014. Role of cave features for aquatic troglobiont fauna occurrence: effects on "accidentals" and troglomorphic organisms distribution. Acta Zoologica Academiae Scientiarum Hungaricae 60:257-270.

Manenti R, and Barzaghi B. 2020. Is landscape of fear of macroinvertebrate communities a major determinant of mesopredator and prey activity? Knowledge and Management of Aquatic Ecosystems. 10.1051/kmae/2019050

Manenti R, and Barzaghi B. In press. Diel activity of Niphargus amphipods in spring habitats. Crustaceana.

Manenti R, and Pezzoli E. 2019. Think of what lies below, not only of what is visible above, or: a comprehensive zoological study of invertebrate communities of spring habitats. The European Zoological Journal, 86:272-279. 10.1080/24750263.2019.1634769

Manenti R, Siesa ME, and Ficetola GF. 2013. Odonata occurence in caves: active or accidentals? A new case study. Journal of Cave and Karst Studies 75:205-209.

\section{$10.4311 / 2012 \mathrm{LSC} 0281$}

Marković V, Novaković B, Ilić M, and Nikolić V. 2018. Epigean Niphargids in Serbia: New Records of Niphargus valachicus Dobreanu \& Manolache, 1933 (Amphipoda: Niphargidae), with Notes on its Ecological Preferences. Acta Zoologica Bulgarica 70:4550. 
541 Mathieu J, Essafi K, and Chergui H. 1999. Spatial and temporal variations of stygobite

542

543

544

545

546

547

548

549

550

551

552

553

554

555

556

557

558

559

560

561

562

563

Amphipod populations in interstitial aquatic habitats of karst floodplain interfaces in France and Morocco. Annales De Limnologie-International Journal of Limnology 35:133-139. 10.1051/limn/1999018

Mathieu J, Essafichergui K, and Jeannerod F. 1994. A gradient of interstitial Niphargus rhenorhodanensis populations in 2 karst floodplain transition zones of the French Jura. Hydrobiologia 286:129-137. 10.1007/bf00006244

Moseley M. 2009. Are all caves ecotones. Cave and Karst Science 36:53-58.

Niemiller ML, Porter ML, Keany J, Gilbert H, Fong DW, Culver DC, Hobson CS, Kendall KD, Davis MA, and Taylor SJ. 2018. Evaluation of eDNA for groundwater invertebrate detection and monitoring: a case study with endangered Stygobromus (Amphipoda: Crangonyctidae). Conservation Genetics Resources 10:247-257. 10.1007/s12686-017$0785-2$

Page MJ, and Moher D. 2017. Evaluations of the uptake and impact of the Preferred Reporting Items for Systematic reviews and Meta-Analyses (PRISMA) Statement and extensions: a scoping review. Systematic Reviews 6. 10.1186/s13643-017-0663-8

Pipan T, and Culver DC. 2012. Convergence and divergence in the subterranean realm: a reassessment. Biological Journal of the Linnean Society 107:1-14. DOI 10.1111/j.10958312.2012.01964.x

Pipan T, and Culver DC. 2013. Forty years of epikarst: what biology have we learned? International Journal of Speleology 42:215-223. 10.5038/1827-806x.42.3.5

Pipan T, Fiser C, Novak T, and Culver DC. 2012. Fifty Years of the Hypotelminorheic: What Have We Learned? Acta Carsologica 41:275-285. 
564 Pirni A. 2016. Space and Anthropology of Limit: A Philosophical Perspective. Frontiers in $565 \quad$ Astronomy and Space Sciences 3. 10.3389/fspas.2016.00022

566 Plenet S, and Gibert J. 1995. A comparison of surface water/ground water interface zones in $567 \quad$ fluvial and karstic systems. Comptes Rendus de l'Académie des sciences 318:499-509.

568 Poulson TL, and White WB. 1969. The cave environment. Science 165:971-981.

569 Prous X, Ferreira RL, and Martins RP. 2004. Ecotone delimitation: Epigean-hypogean transition 570 in cave ecosystems. Austral Ecology, 29:374-382.

571 Reboleira A, Borges PAV, Goncalves F, Serrano ARM, and Oromi P. 2011. The subterranean 572 fauna of a biodiversity hotspot region - Portugal: an overview and its conservation. 573 International Journal of Speleology 40:23-37. 10.5038/1827-806x.40.1.4

574 Rechulicz J. 2011. Monitoring of the Topmouth Gudgeon, Pseudorasbora Parva (Actinopterygii:

575 Cypriniformes: Cyprinidae) in a Small Upland Ciemiega River, Poland. Acta $576 \quad$ Ichthyologica Et Piscatoria 41:193-199.

577 Rohde MM, Froend R, and Howard J. 2017. A Global Synthesis of Managing Groundwater 578 Dependent Ecosystems Under Sustainable Groundwater Policy. Groundwater 55:293$579 \quad 301.10 .1111 /$ gwat. 12511

580 Romero A. 2009. Cave biology. New York: Cambridge University Press.

581 Rouch R. 1986. Sur l'écologie des eaux souterraines dans le karst. Stygologia 2:352-398.

582 Salvidio S, Costa A, Oneto F, and Pastorino MV. 2020. Variability of A Subterranean Prey583 Predator Community in Space and Time. Diversity-Basel 12. 10.3390/d12010017

584 Silva MS, Iniesta LFM, and Ferreira RL. 2020. Invertebrates diversity in mountain Neotropical 585 quartzite caves: which factors can influence the composition, richness, and distribution of 586 the cave communities? Subterranean Biology 33:23-43. 10.3897/subtbiol.33.46444 
587 Sket B. 2008. Can we agree on an ecological classification of subterranean animals? Journal of

588

589

590

591

592

593

594

595

596

597

598

599

600

601

602

603

604

605

606

607

608

609 Natural History 42:1549-1563. DOI: 10.1080/00222930801995762

Springer AE, and Stevens LE. 2009. Spheres of discharge of springs. Hydrogeology Journal 17:83-93. 10.1007/s10040-008-0341-y

Stoch F, Gerecke R, Pieri V, Rossetti G, and Sambugar B. 2011. Exploring species distribution of spring meiofauna (Annelida, Acari, Crustacea) in the south-eastern Alps. Journal of Limnology 70:65.

Sturz BR, and Bodily KD. 2016. Detecting the perception of illusory spatial boundaries: Evidence from distance judgments. Cognition 146:371-376. 10.1016/j.cognition.2015.10.015

Thomsen PF, Kielgast J, Iversen LL, Wiuf C, Rasmussen M, Gilbert MTP, Orlando L, and Willerslev E. 2012. Monitoring endangered freshwater biodiversity using environmental DNA. Molecular Ecology 21:2565-2573.

Trajano E, and De Carvalho MR. 2017. Towards a biologically meaningful classification of subterranean organisms: a critical analysis of the Schiner-Racovitza system from a historical perspective, difficulties of its application and implications for conservation. Subterranean Biology 22:1-26.

Vandel A. 1920. Sur la faune des sources. Bulletin De La Societe Zoologique De France 45:177 $-183$.

Vandel A. 1964. Biospeleologie: la biologie des animaux cavernicoles. Paris: Gauthiers-Villars. Vilenica M, Previsic A, Kucinic M, Gattolliat JL, Sartori M, and Mihaljevic Z. 2016. Distribution and Autecology of Mayflies (Insecta, Ephemeroptera) in a Mediterranean River in the Western Balkans. Entomological News 126:19-35. 
610 Von Fumetti S, and Nagel P. 2011. A first approach to a faunistic crenon typology based on 611 functional feeding groups. Journal of Limnology 70:147-154.

612 West KM, Richards ZT, Harvey ES, Susac R, Grealy A, and Bunce M. 2020. Under the karst: 613 detecting hidden subterranean assemblages using eDNA metabarcoding in the caves of 614 Christmas Island, Australia. Scientific Reports 10. 10.1038/s41598-020-78525-6

615 White NE, Guzik MT, Austin AD, Moore GI, Humphreys WF, Alexander J, and Bunce M. 2020. 616 Detection of the rare Australian endemic blind cave eel (Ophisternon candidum) with 617 environmental DNA: implications for threatened species management in subterranean 618 environments. Hydrobiologia 847:3201-3211. 10.1007/s10750-020-04304-z

619 White WB. 2019. Springs. In: White WB, Culver DC, and Pipan T, eds. Encyclopedia of Caves. 620 Cambridge, MA, USA: Academic Press, $1031-1040$.

621 Yonezawa S, Nakano T, Nakahama N, Tomikawa K, and Isagi Y. 2020. Environmental DNA 622 reveals cryptic diversity within the subterranean amphipod genus Pseudocrangonyx 623 Akatsuka \& Komai, 1922 (Amphipoda: Crangonyctoidea: Pseudocrangonyctidae) from 624 central Japan. Journal of Crustacean Biology 40:479-483. 10.1093/jcbiol/ruaa028 625 


\section{Table $\mathbf{1}$ (on next page)}

Table 1

Table 1. Search terms and inclusion/exclusion criteria used to describe published evidence of stygobionts in springs and to answer specific questions. 
Table 1

\begin{tabular}{|c|c|}
\hline Categories & Restrictions applied \\
\hline Number of species mentioned & If clearly stated for all taxa considered in the study \\
\hline Stygofauna found in springs & If clearly stated that the species found in springs are stygobites \\
\hline $\begin{array}{c}\text { Number of stygofaunal species in } \\
\text { springs }\end{array}$ & $\begin{array}{l}\text { If the number of stygobite species found in } \\
\text { springs is clearly stated for all taxa considered in the study }\end{array}$ \\
\hline Surface fauna found underground & $\begin{array}{l}\text { If clearly stated that the species found underground are of } \\
\text { epigean origin }\end{array}$ \\
\hline $\begin{array}{l}\text { Number of surface species found } \\
\text { underground }\end{array}$ & $\begin{array}{l}\text { If the number of epigean species found underground is clearly s } \\
\text { tated for all taxa considered in the study }\end{array}$ \\
\hline $\begin{array}{l}\text { Species found both in caves and } \\
\text { springs }\end{array}$ & $\begin{array}{l}\text { If clearly stated that the species found both in caves and springs } \\
\text { are epigean or stygobites }\end{array}$ \\
\hline $\begin{array}{c}\text { Number of species in both (caves } \\
\text { and springs) }\end{array}$ & $\begin{array}{c}\text { If the number of stygobites or epigean species found in both is } \\
\text { clearly stated for all taxa }\end{array}$ \\
\hline Ecology & $\begin{array}{l}\text { Yes/no, depending on whether the paper provides original } \\
\text { ecological information } \\
\text { (habitat of occurrence, environmental drivers etc..) }\end{array}$ \\
\hline Taxonomy & $\begin{array}{c}\text { Yes/no, depending on whether the paper provides original } \\
\text { taxonomic data }\end{array}$ \\
\hline Behavior & $\begin{array}{l}\text { Yes/no, depending on whether the paper tests/reports original } \\
\text { behavioral information/observations }\end{array}$ \\
\hline Conservation & $\begin{array}{l}\text { Yes/no, depending on whether the paper explores original } \\
\text { conservation/restoration problems or actions }\end{array}$ \\
\hline Faunal assessment & $\begin{array}{l}\text { Yes/no, depending on whether the paper is mainly devoted to } \\
\text { assess faunal composition of spring/groundwater habitat }\end{array}$ \\
\hline
\end{tabular}

2 Table 1. Search terms and inclusion/exclusion criteria used to describe published evidence of 3 stygobionts in springs and to answer specific questions. 


\section{Table 2 (on next page)}

Table 2

Table 2. Number of papers reporting observations of stygofauna in springs, of surface fauna in groundwaters, and of the same taxa in both environments. Papers are divided based on the key words used for the systematic review: GF, groundwater fauna; SFF, spring freshwater fauna. 


\section{Table 2}

2

3

\begin{tabular}{cllll}
\hline & Total & GF & SFF \\
\hline $\begin{array}{c}\text { Stygofauna } \\
\text { in springs }\end{array}$ & YES & 57 & 49 & 8 \\
& Information missing & 50 & 195 & 40 \\
\hline $\begin{array}{c}\text { Surface } \\
\text { fauna }\end{array}$ & YES & 37 & 31 & 19 \\
$\begin{array}{l}\text { underground } \\
\begin{array}{l}\text { Same taxa } \\
\text { both in }\end{array}\end{array}$ & YES & 278 & 34 & 3 \\
$\begin{array}{l}\text { Springs and } \\
\text { groundwaters }\end{array}$ & NO & 27 & 220 & 58 \\
\hline
\end{tabular}

4 Table 2. Number of papers reporting observations of stygofauna in springs, of surface fauna in

5 groundwaters, and of the same taxa in both environments. Papers are divided based on the key

6 words used for the systematic review: GF, groundwater fauna; SFF, spring freshwater fauna. 


\section{Table 3 (on next page)}

Table 3

Table 3. The reported occurrence of stygofauna in springs, of surface fauna in groundwaters, and of the same taxa in both habitats shown as a function of study discipline. Relationships were assessed using generalized linear models (GLMs) followed by a likelihood ratio test. Significant relationships are reported in bold. 
1 Table 3

\begin{tabular}{clrrrr}
\hline & Research discipline & Estimate & \multicolumn{1}{l}{ SE } & \multicolumn{1}{l}{$\chi^{2}$} & \multicolumn{1}{l}{$P$} \\
\hline & Ecology & 0.27 & 0.34 & 0.64 & 0.42 \\
& Taxonomy & 0.75 & 0.39 & 3.67 & 0.06 \\
Stygofauna in springs & 0.24 & 0.35 & 0.48 & 0.49 \\
& Faunal assessment & 0.67 & 0.53 & 1.50 & 0.22 \\
& Conservation & -13.84 & 834.76 & 0.98 & 0.32 \\
\hline & Behavior & 0.02 & 0.41 & 0.00 & 0.96 \\
& Ecology & 0.27 & 0.50 & 0.29 & 0.59 \\
& Taxonomy & 1.09 & 0.45 & 6.62 & $\mathbf{0 . 0 1}$ \\
Surface fauna underground & Faunal assessment & 0.51 & 0.59 & 0.68 & 0.41 \\
& Conservation & 1.30 & 1.20 & 0.94 & 0.33 \\
\hline & Behavior & 0.09 & 0.43 & 0.04 & 0.84 \\
& Ecology & 0.91 & 0.45 & 3.96 & $\mathbf{0 . 0 4}$ \\
& Taxonomy & 0.06 & 0.44 & 0.02 & 0.89 \\
Same taxa both in springs and & Faunal assessment & 0.77 & 0.60 & 1.45 & 0.23 \\
& Conservation & -13.15 & 839.90 & 0.51 & 0.48 \\
\hline
\end{tabular}

2 Table 3. The reported occurrence of stygofauna in springs, of surface fauna in groundwaters, and

3 of the same taxa in both habitats shown as a function of study discipline. Relationships were

4 assessed using generalized linear models (GLMs) followed by a likelihood ratio test. Significant

5 relationships are reported in bold. 


\section{Figure 1}

Figure 1

Figure 1. Diagram of a spring showing differences between surface and groundwater habitats during day $(A)$ and night $(B)$. During night the border between surface waters and groundwaters softens and stygobionts can move outside interacting with surface invertebrates and vertebrates including predators (here represented by a diurnal predator fish and a nocturnal predator salamander larva). White silhouettes represent stygobionts, black silhouettes represent potential predators (fish and salamanders), and brown silhouettes surface aquatic invertebrates. Drawing is modified from Andrea Melotto and Benedetta Barzaghi (unpublished).
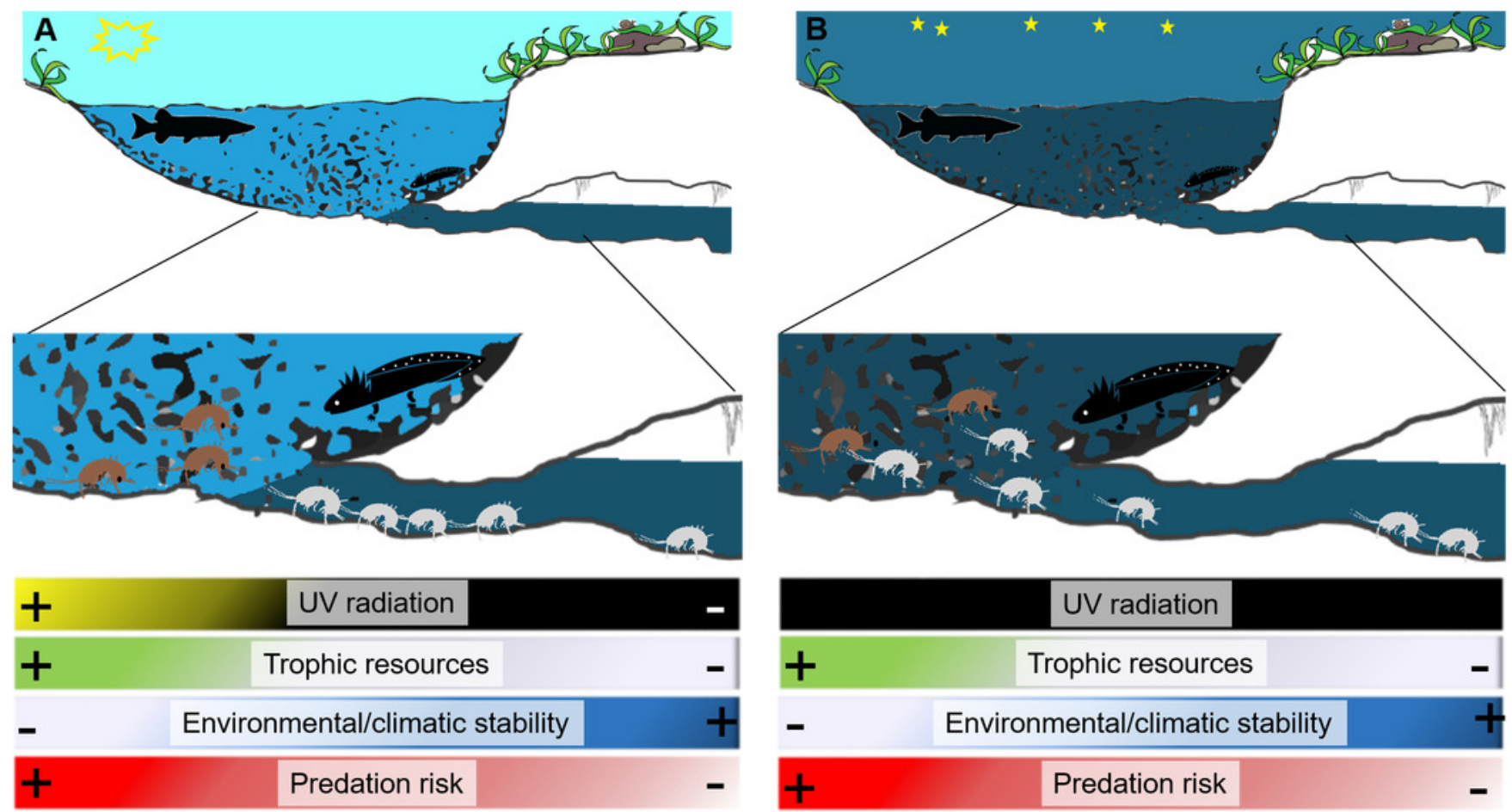
Figure 2

Figure 2

Figure 2 PRISMA 2020 flow diagram for the systematic reviews which included search of Web of Science database only. 
Identification of studies via databases and registers

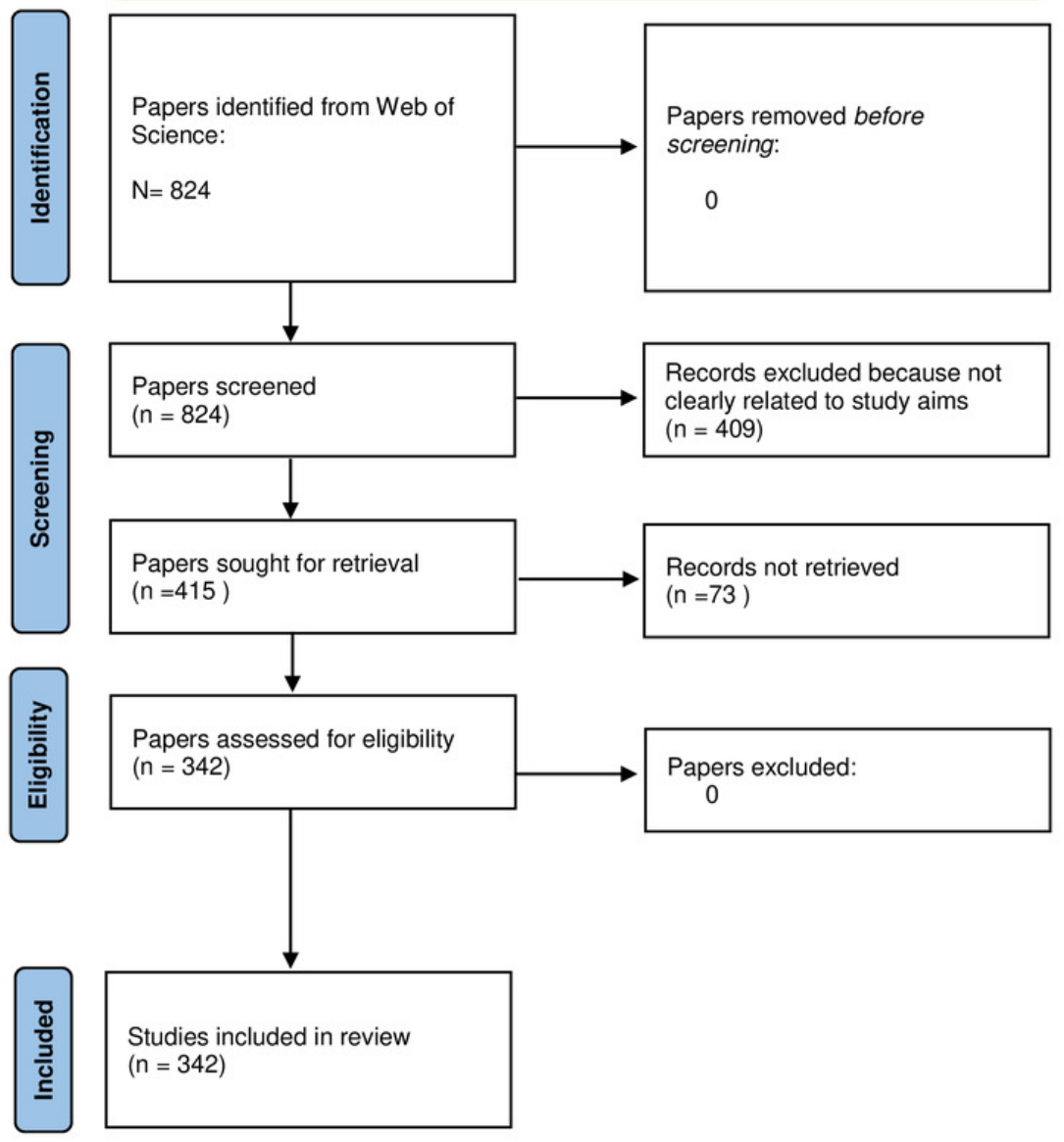

